$\begin{gathered}\text { LOCAL WISDOM, 11 (2): 146-157,2019 } \\ \text { Local Wisdom Scientific Online } \\ \text { Journal } \\ \text { ISSN: 2086-3764 }\end{gathered} \mid \begin{array}{r}\text { WISDOM } \\ \mathrm{w}\end{array}$

\title{
Identification of Architectural Ornaments of Santo Albertus Jetis Church Yogyakarta
}

\author{
Sidhi Pramudito ${ }^{*}$, Gerarda Orbita Ida Cahyandari ${ }^{2}$, Muhammad Ikhsan Arifin ${ }^{3}$ \\ 1Laboratorium Perencanaan dan Perancangan Bangunan Arsitektural \\ 2Program Studi Arsitektur Fakultas Teknik Universitas Atma Jaya Yogyakarta \\ Corresponding Author: sidhi.pramudito@uajy.ac.id
}

\begin{abstract}
Keywords:

Renovation activities can improve quality or even reduce the quality of ornament, mangunwijaya, santo albertus church jetis, yogyakarta a building due to the loss of special elements in the building. One of the elements in a building that can give special features to an architectural work is ornament. The aim of this study was to identify ornamental design principles that can be found in several works of Mangunwijaya and their application to the buildings of the Santo Albertus Church in Jetis Yogyakarta. This research using descriptive methods through case studies in the field with analysis through qualitative methods. The methods of retrieving data through direct observation and documentation and supported by literature studies. The results of this study indicate that the ornaments on the Santo Albertus Church has flora and fauna motifs that are made in a combination style and have a style of contemporary ornaments, and the ornaments that are made have a propensity to affect the spirit of the space. Based on these results, it is expected to be a suggestion and consideration for the renovation activities that are currently being carried out, especially in understanding the use and meaning of the ornament, so the building of the Church of Santo Albertus Jetis did not lose the identity.
\end{abstract}




\section{Introduction}

In architecture, the role of building maintenance is crucial. This activity is a responsibility to take after a building occupied to make it liveable as has been planned in the design. One of maintenance activities called renovation. It is a combination of technical and administrative work to preserve and restore the function of a building as has been planned. The problem that may emerge in maintaining a building is the one connected to historical values, i.e. architectural, city, or cultural values that may conflict with some functional, technical and performance demands as well as legislation and ownership (Busono).

Such a controversion occured in one of Romo Mangunwijaya's works, i.e. Santo Albertus Agung Church Jetis in Yogyakarta. This Church was once a part of Kotabaru Church Yogyakarta service area for the people who resided on the west bank of Code River. Santo Albertus Agung Church Jetis was built in November 1965 as an initiative and result of struggle of some figures. In general, locality is sound in this Church design. At that time, Catholic churches would usually be designed following the Dutch church style. However, Santo Albertus Agung Church Jetis is different, where honesty and simplicity are emerged in the building. Luxury and elegance are depicted in the shapes and ornament of local culture which are aimed at accentuating local art work (Tanuwidjaja, 2013).

What makes Romo Mangunwijaya's works of architecture distinctive is indicated in his visions written in a book 'Wastu Citra'. 'Wastu Citra' means humans' creativity in standing for the truth and merit of pilgrimage so that their self images reflect truth, kindness and beauty. For Mangunwijaya, architectural works should carry messages. His model of architecture is a vocal criticism against people's tendency to build houses and public skyscrapers which are swanky and far from the values of local culture. In each of Mangunwijaya's works, values of appreciating local culture, humanism and contextuality are depicted (Mulyanto, November 2013).

This study is of architectural ornament of Santo Albertus Agung Church Jetis. It is significant due to the plan for renovating and expanding the Church in which Romo Mangunwijaya's works are crafted. This study aims to investigate Mangunwijaya's concept of design by studying his ornament characteristics in general and that of Santo Albertus Agung Church in particular. Ornament is picked to be the object of this study because in Catholic churches, it is an important symbol to deliver ecclesiastical values to the worshippers. This study is expected to be an architectural reference and ecclesiastical principle development, which is contextually appropriate for the future.

\section{Literature Review}

\subsection{Ornament}

Ornament comes from the word "ornare" which means to decorate. It can also mean a decoration(s) or an accessory (ies), then it is also acceptable to define it as a decorative design. Another definition says that ornament is all kinds of geometric decorations and those of other shapes. Ornament is also the basic form of crafts, including that of architecture. In general, ornament is a decoration of a particular shape or symbol to adorn one thing; or something that is painted, carved and printed to add values to a certain thing.

Ornament is classified into two types: passive and active. Passive ornament is the one that functions only as a decoration, and has nothing to do with supporting a building's structure; while active ornament may function both as a decoration as well as an element of the building's structure. Other than that, ornament can also function as a pure decoration or a symbolic decoration. Talking about ornament in architecture, there are some features to make its function more clear such as motif, style (used in the making), period and physical 
characters, and function. Motif means the basic element in making ornament of a work. Ornament motif consists of: (1) geometry; (2) flora; (3) fauna; (4) human; and (5) nature. Way or style used to make an ornamnet can be classified into: (1) Realism or naturalism; (2) Stylirisation or arrangement; and (3) Combination or creation. Based on the period and characteristic, ornament has some styles: (1) Primitive ornament; (2) Classical ornament; (3) Traditional ornament; (4) Contemporary/modern ornament (I Wayan Sudana, 2005).

\subsection{Ornament Placement in Architecture}

In architecture, ornament can be grouped into two types, i.e. exterior and interior. Exterior ornament is placed on a building's corners, center (symmetrical), bottom, roof ridge, crossing or one side of facade, so as to accentuate a certain image of the building. Interior ornament placement is to intensify a room's atmosphere and aesthetics, and is applied on the column, floor, enclosures like walls, doors, windows, and ceiling or plafond (Brent C. Brolin, 1982).

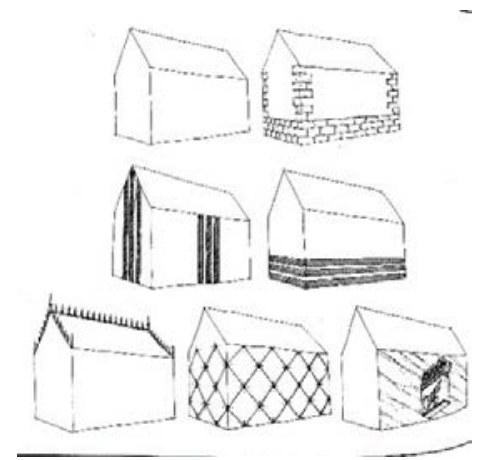

Figure 1. Types of Ornament Placement in Building Source: Source Book of Architectural Ornament

\subsection{General Review of Church Ornament}

Ornament usage in churches is more of Religious Symbolism. It is an architectural symbol(s) or form(s), the art of an occurence or natural phenomena which is connected to a certain religion. Religious Symbolism aims to foster strong solidity among its worshippers, and to guide them to get closer to the worshipped God (Siwu, 2016). Symbolization in churches is different from one another and dynamic because of its interaction with local cultures and the social life of the people in a certain period.

\subsection{Review on Architectural Tectonics}

Tectonics, refering to Adolf Heinrich Borbein's study of philology in 1982, means The Art of Joinings. Frampton has two views about tectonics, i.e. historically and semantically. Both are the points by which Frampton interpretes architecture. In his opinion, architectural tectonics can be read from its history and development as well as from its purpose.

Connected to both views, Frampton is concerned on Karl Friederich Schinkel's thoughts in his book 'The Principle of Art in Architecture'. According to Karl Friederich Schinkel, there are four principles in architecture, i.e. (a) Building is to join different materials to be one unity. (b) This definition covers aspects of architecture symbolism and representation, which clearly shows its final goal as the main principle of architecture. (c) The main focus is on the materials which are considered a spiritual aspect. (d) The purpose of a building can be viewed from three aspects, i.e. (1) the purpose of room distribution on the design, (2) the purpose of the construction or connected materials as in the design, and (3) the purpose of ornament or decorations. 


\section{Identification of Architectural Ornaments of Santo Albertus Jetis Church Yogyakarta Sidhi Pramudito, Gerarda Orbita Ida Cahyandari, Muhammad Ikhsan Arifin}

The point to which we need to pay more attention is the fourth one,. i.e. three main purposes of a building. When juxtaposed to Semper and Botticher's theory of tectonics, we can say that each element has to be studied when investigating the building's tectonics. This is reconnected to three main elements in architecture according to Vitruvius in Vitruvian Triangle, i.e. utility, firmness and venustas. In brief, each element is explained as follows: (a) utility is a building's tectonics from its rooms/space. (b) firmness, building's tectonics from its structural elements. (c) Venustas, a building's tectonics from its ornamental elements (Leevianto, Volume 01, Number 02, April 2017 Edition).

\subsection{Characteristics of Mangunwijaya's Ornament}

Romo Mangunwijaya's works of architecture can not be separated from 'guna' and 'citra'. 'Guna' is the function of a building and 'citra' is its representation of a certain meaning. Both are inspired by a philosopher called A. Merleu Ponty. He said that, "Body is some room that emerges in itself, ... not only it is a physical thing, but more of a work of art..." (Mangunwijaya, 1988). For that matter, architecture as a human's work of art is said to be a body or room who has to be able to reveal its true identity. Someone who talks, gets dressed and works architecture out is to reveal his identity.

According to this believe, revealing the characteristics of a work of design becomes urgent as a medium to find out its designer's identity. In this part, investigating the characteristics of Romo Mangunwijaya's architectural ornament was done by looking at the one in his other works. It was then compared to that of Santo Albertus Agung Church Jetis.

\subsubsection{Maria Asumta Church, Klaten}

Ornament in this Church is divided into two parts, i.e. exterior and interior. The exterior ornament is placed on the roof's ridge end and outer walls. The interior ornament is found on the inner walls and on the aperture of the Church's enclosures.

The shape of the ridge end is a metaphore of praying crossed-fingers. On the wall of the outer enclosures are crafted tree-shaped blue ornament on which illustrations are placed, which mean life and all it brings (humans, animals, plants, water, air and fire) and whose top part is upward. The trees and illustrations depict the relation of humans, the universe and their God.

The aperture wall of the church's interior functions as the air circulation and natural lighting. It is a concept of Javanese traditional house which is open and friendly with Indonesia's tropical nature (macrocosmos). Moreover, the aperture also adds an aesthetical value because the three gaps on the central wall symbolizes Allah the Trinity. On the interior wall, there is also found leaf ornament made from printed plaster wall. This ornament symbolizes simplicity and silence as well as closeness to the nature.

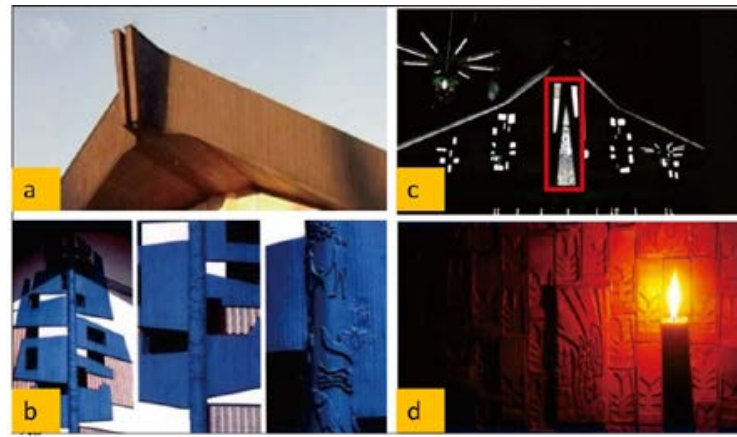

Figure 2. a. Roof Ridge Ornament; b. The Outer Wall Ornament; c. Ornament on the Openings of Church Room; d. The Church Interior Wall Ornament (Source: Adikarya Postcard of Y.B. Mangunwijaya on (Setyoningrum, 2012)) 


\subsubsection{Sendangsono Pilgrimage Complex, Kulonprogo}

Ornament in this pilgrimage complex is placed on the exterior including the wall bordering Sendangsono with its surrounding area, the wall bordering the 'cross road', the Amphiteatre of the Apostles Chapel and the meditating terrace. On the wall bordering Sendangsono from the surrounding area is found ornament of three lines and circles. The lines represent God the Father, the Son Jesus and the Holy Spirit. The circles represent unity. When combined, the Three lines and the Circles represent Doctrine of the Trinity.

On the wall bordering the 'cross road', rose ornament is found. Roses symbolize women's love and femininity. The love in question is that of the Virgin Mary's to Jesus, her Son. Femininity implies the Virgin Mary as Jesus' Mother. On the wall of the Amphiteatre of the Apostles Chapel, and the meditating terrace a 'jalu mampang' grass' ornament is found. 'Jalu mampang' is a kind of weeds that is found every where. This grass symbolizes populism and modesty. The grass implies that all humans are equal.
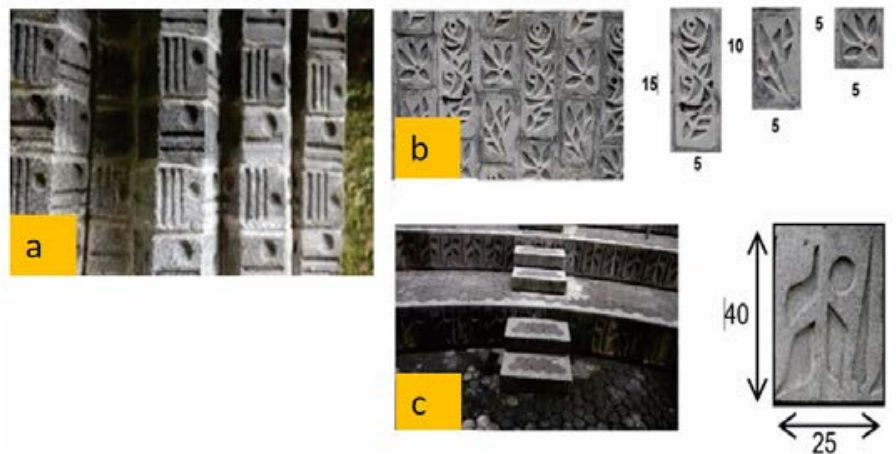

Figure 3. The Ornament which placed on Exterior Bordering Wall Sendangsono: a. The Exterior; b. The Ornament which placed in the wall bordering the 'cross road' / jalan salib; c. Ornamen which placed in amphiteatre of the Apostles Chapel and The Meditating Terrace

(Leevianto, Volume 01, Nomor 02, edisi April 2017)

\subsubsection{Ornament Characteristics on Romo Manguwijaya's Works}

From both of Romo Mangunwijaya's works, it is revealed that they have distinctive features that define his uniqueness, e.g.:

- The application of easily found materials that can be used as efficient as possible so as to give impact on the people of the surrounding area and to press the building cost.

- Romo Mangunwijaya's ornament is not only decorative but also implicitly meaningful.

- The ornament is obviously seen on the walls of both works, i.e. floral motif.

- The ornament of both works are made by using stylization.

\section{Method}

This study is of descriptive, through a field case study analyzed by using qualitative technique. The data was collected by doing direct observation and documentation and supported by literature review. The results were then analyzed by reviewing the literature about aspects in the architectural theory(s) including placement, motif, style, color, functions and philosophy. The analysis was done in several stages: (1) tracing the characteristics of architectural ornament in Mangunwijaya's works of religious buildings; (2) clarifying the 
caracteristics of Mangunwijaya's architectural ornament with that of Santo Albertus Agung Church Jetis Yogyakarta.

This study aims to explore the ornament styles of Mangunwijaya's works in relation with the up coming renovation of Santo Albertus Agung Church Jetis Yogyakarta. The building is one of Mangunwijaya's works and is more than 50 years old. The increasing number of people and activities in the Church makes it urgent to redesign the building. This study is expected to give the upcoming renovation some advice and suggestions, particularly in understanding the ornament's functions and meanings so as to make the Church does not lose its identity.

\section{Results and Discussion}

\subsection{General Description on Santo Albertus Agung Church Jetis Yogyakarta}

Santo Albertus Agung Church Jetis is a Chatholic Church that belongs to the service of Keuskupan Agung Semarang (KAS/Archdiocese of Semarang). This Church sits at Jl. A. M. Sangaji No. 20, Cokrodiningratan, Jetis, Yogyakarta City, the Special Region of Yogyakarta. Administratively Santo Albertus Agung Church Jetis is directly adjacent to Sleman Regency in the north, Gondokusuman District in the east, Gedong Tengen District in the south, and Tegalrejo District in the west. The Church has a land area of approximately $3,900 \mathrm{~m} 2$ with the main Church building area of approximately $512.8 \mathrm{~m} 2$.

Santo Albertus Agung Church Jetis got a first-hand touch of Romo Mangunwijaya in the interior and exterior. The concepts, philosophy and ideas that make Romo Mangunwijaya distinctive are obviously seen in this Church, then studying about the building is of great interest.

The people who want to worship enter the main Church through the east and south wings, and when the main building is already full, both wings will be used, particularly the east one as they are joint together so that the altar can still be seen. However, off the south part, there are bordering windows and door which block people worshipping in the south wing from the altar in the main building. It shows that this wing used to be an additional area for worshipping due to the increasing number of worshippers.

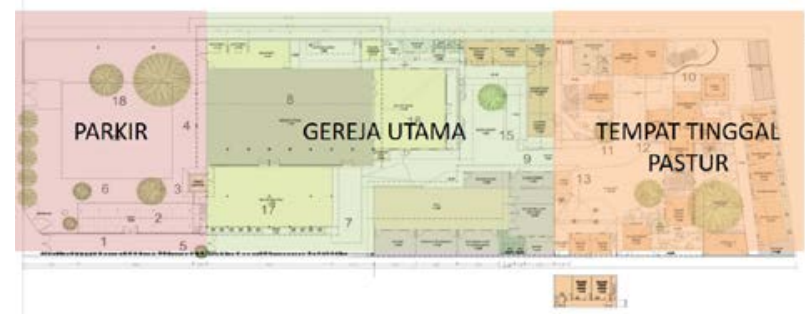

Figure 4. Site Plan dan Zonasi Gereja Santo Albertus Agung Jetis Yogyakarta Source: Kajian Rencana Pengembangan Gereja St. Albertus Agung Jetis, Yogyakarta

In general, the layout of Santo Albertus Agung Church Jetis has a composition consisting of three squares configuring an ' $L$ '. This configuration consists of the Church's main room, the east wing and the south wing. Connecting the main room and both wings are doors. Both wings will function as worshipping space when the main room can no longer hold all of the worshippers. The mass shapes of the Church are triangle and rectangle. The triangle is embodied in the 'pelana kampong' roof and the rectangle in the building. There is a 'gunungan-shaped' (gunung: volcano) ornament on the facade facing Jl. A.M. Sangaji from which it can be obviously recognized. 

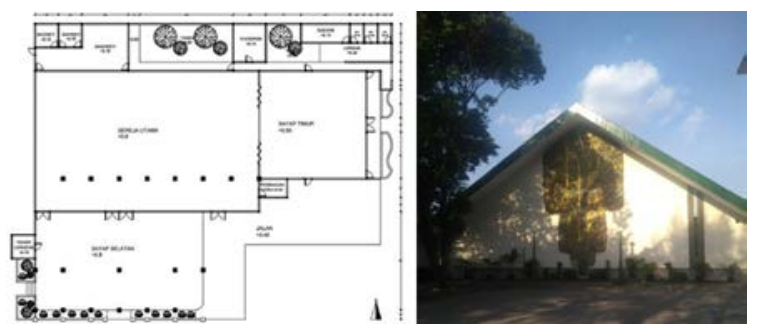

Figure 5. Denah dan Fasad Gereja Santo Albertus Agung Jetis Yogyakarta Source: Author Documentation

\subsection{Review of Ornament in Santo Albertus Agung Church Jetis Yogyakarta}

According to Eko Prawoto, a colleague as well as student of Romo Mangunwijaya, in designing a building, he highly upholds local values such as tropical climate, culture, people that are transfered into each architectural design element. He also took material's nature and characteristics into considerations to use through architectural tectonics. Honesty and modesty are the impressions highlighted in all Romo Mangunwijaya's design of churches by placing ornament taken from local culture to highlight local artwork (Tanuwidjaja, 2013).

Santo Albertus Agung Church Jetis is designed by Romo Mangunwijaya and brings philosophical as well as local values so as to make it distinctively special when compared to other churches in Indonesia. One of the distinctions is recognized on the exterior and interior ornament. A further study is necessary to do so that when the renovation time is coming up, this Church will not lose its distinction.

\subsection{Interior Ornament}

The interior ornament can be classified into several several observation objects such as columns, floors, building enclosure (walls, doors and windows), ceilings and roof constructions. The following is an explanation of interior ornaments in the Santo Albertus Agung Church Jetis.

Table 1. Identification of Interior Ornament

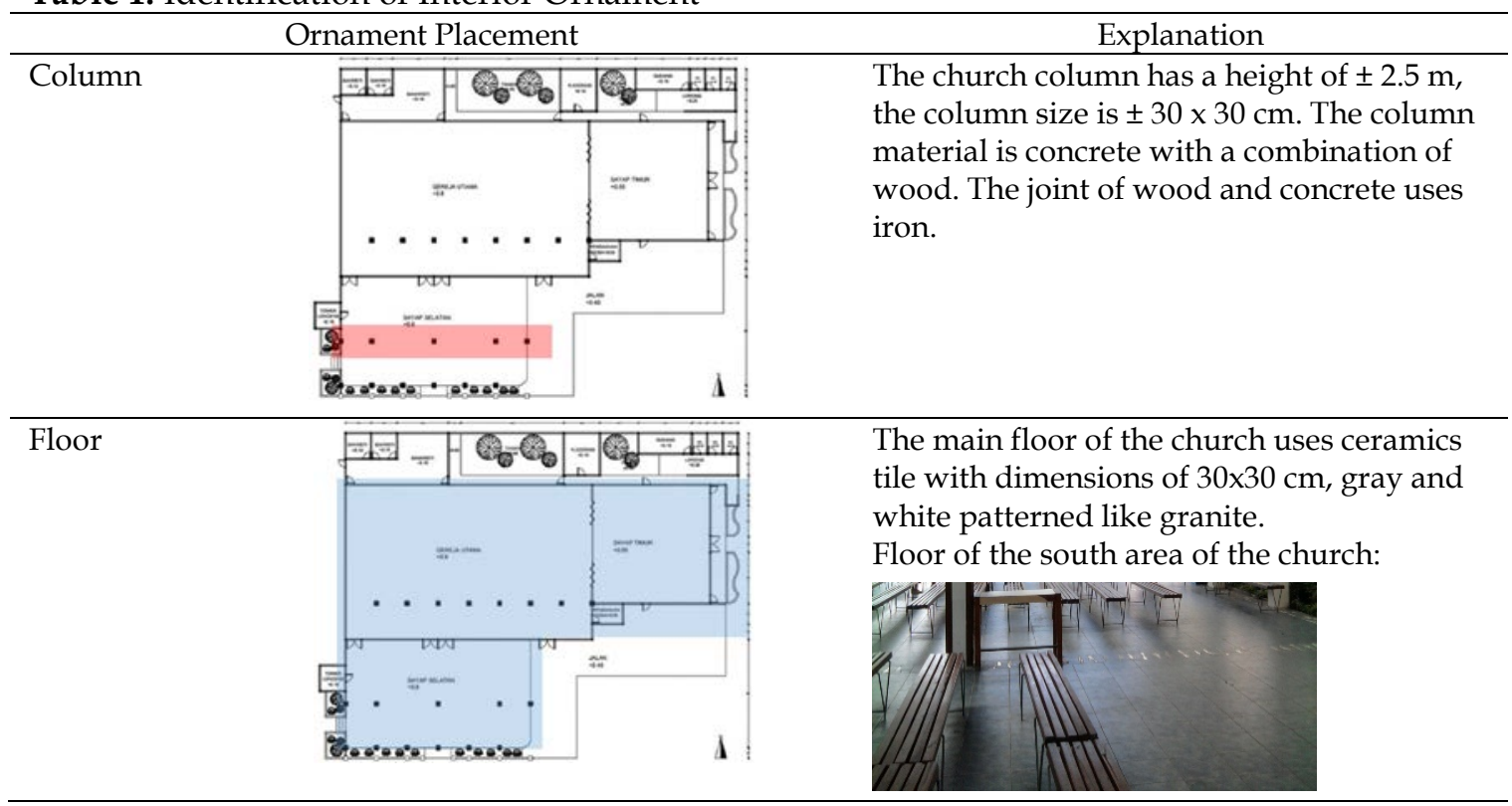


Identification of Architectural Ornaments of Santo Albertus Jetis Church Yogyakarta Sidhi Pramudito, Gerarda Orbita Ida Cahyandari, Muhammad Ikhsan Arifin

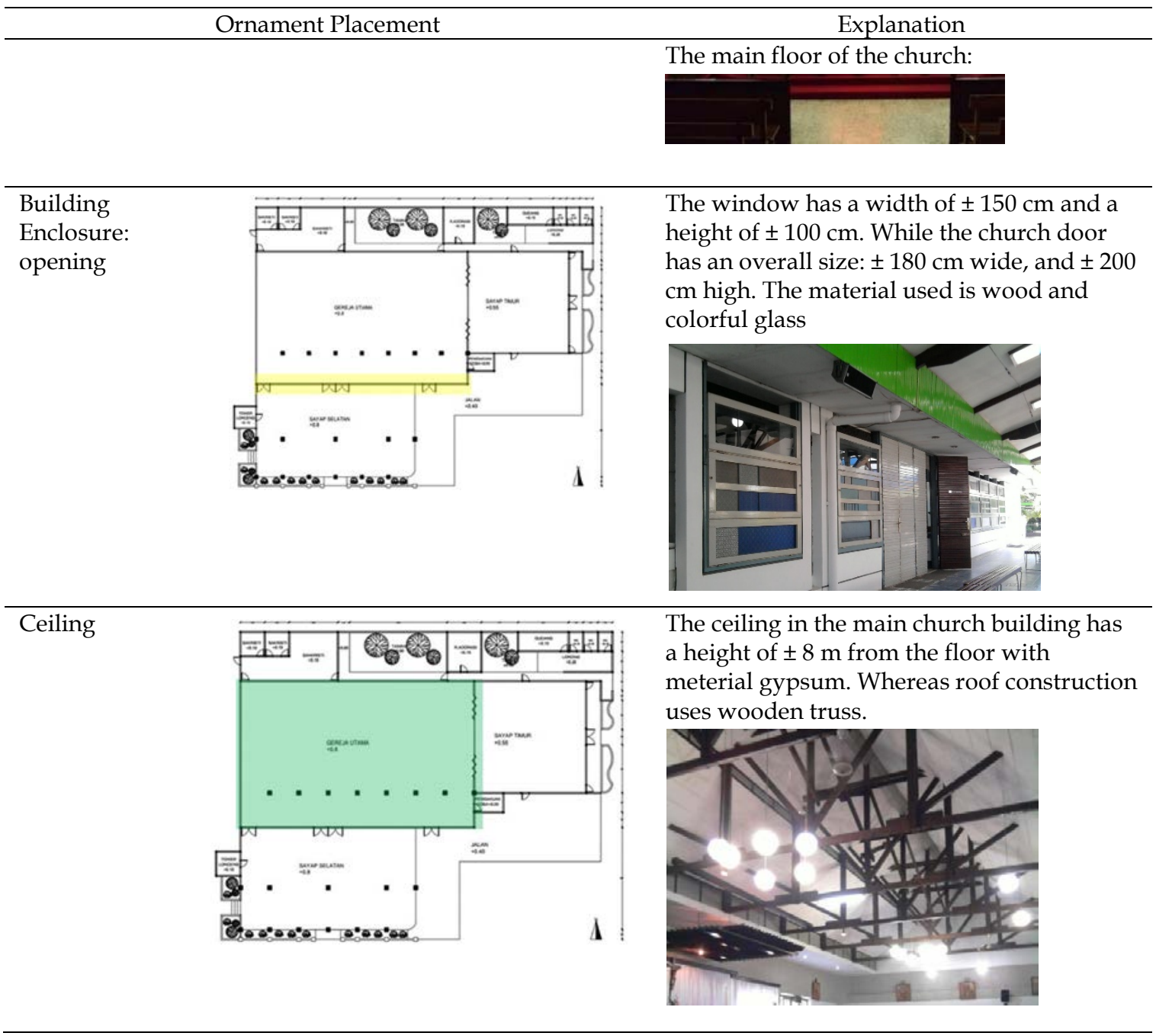

\subsection{Exterior Ornament}

Ornaments on the exterior can be classified according to the position of the ornament placement on the facade, which is in the facade corner, the center of the building, the bottom of the building, and crossing, in the hip rafter of the roof.

Table 2. Identification of Exterior Ornament

\begin{tabular}{ll}
\hline Edge corner & Explanation \\
façade & $\begin{array}{l}\text { Ornaments in the facade } \\
\text { are a list or brown lines } \\
\text { and cavities equipped } \\
\text { with glass that has a } \\
\text { width of } \pm 20 \mathrm{~cm}, \text { and a } \\
\text { height of } \pm 200 \mathrm{~cm}, \text { with } \\
\text { glass material and } \\
\text { cement plastering. }\end{array}$ \\
\end{tabular}




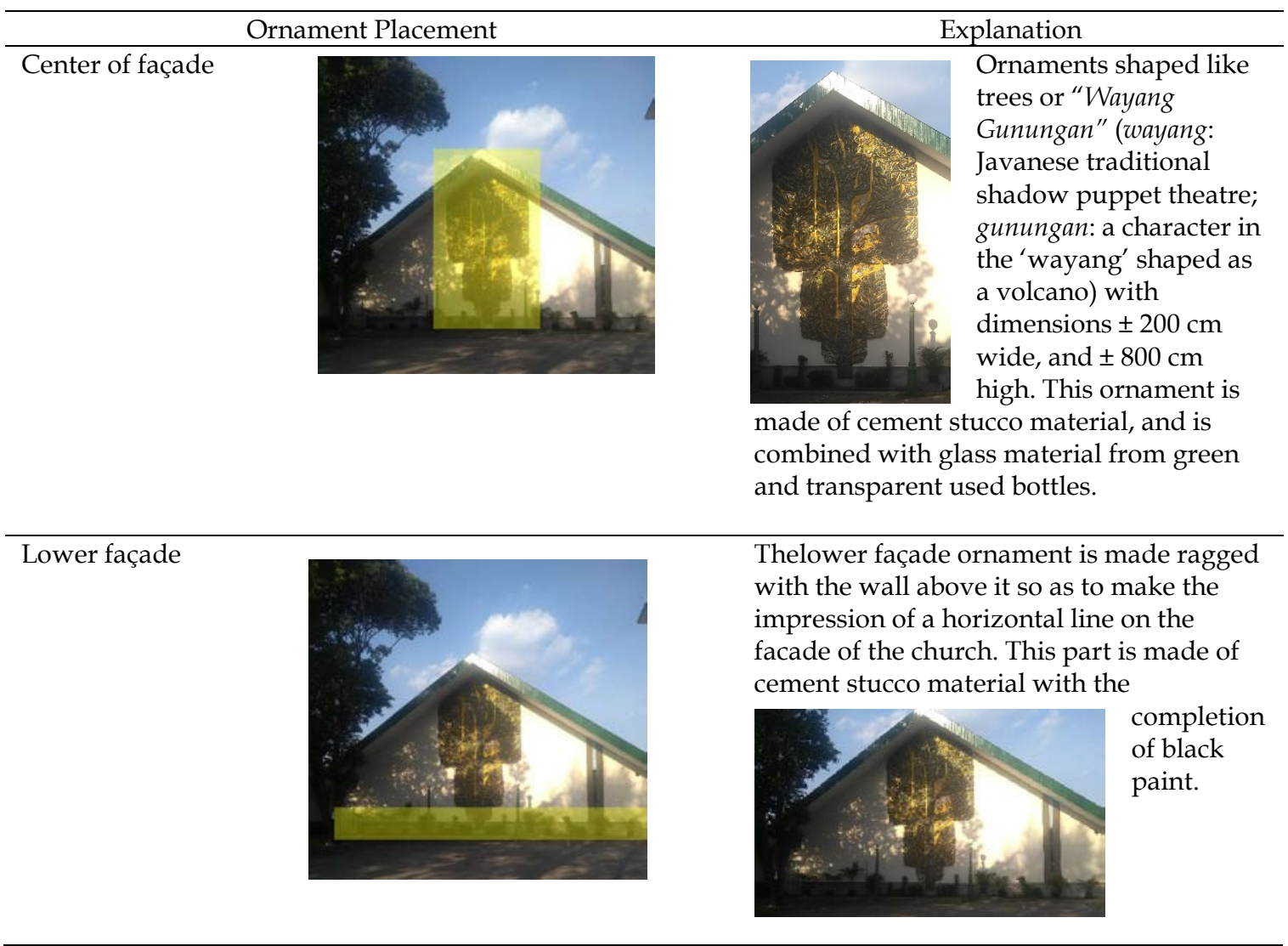

\subsection{Ornament in Santo Albertus Agung Church Jetis Yogyakarta}

Some ornament in Santo Albertus Agung Church Jetis were not created by Romo Mangunwijaya but by other people because they wanted to continue what he had made. For that matter, we have to be careful in identifying the ornament so that we would know which were created by Romo Mangunwijaya and which were not by analyzing his other two masterpieces, i.e.Maria Asumpta Church Klaten and Sendangsono Pilgrimage Complex Kulonprogo. Among all ornament, those which was genuinly created by Romo Mangunwijaya was: (1) the one on the facade; (2) the one on the ceiling; and (3) the one on the enclosures/walls. Based on that brief explanation, the following is the detailed description about the Church:

Table 3. Analysis of Romo Mangunwijaya's Original Ornaments in Jetis Church based on ornamental theory

\begin{tabular}{|c|c|c|c|c|}
\hline $\begin{array}{l}\text { Ornament } \\
\text { Placement }\end{array}$ & Ornament Motif & Ornament Style & $\begin{array}{l}\text { Ornament } \\
\text { Pattern }\end{array}$ & $\begin{array}{l}\text { Ornament's Function } \\
\text { and Philosophy }\end{array}$ \\
\hline $\begin{array}{l}\text { The western } \\
\text { facade of the }\end{array}$ & $\begin{array}{l}\text { In the facade of } \\
\text { the church there } \\
\text { are ornaments } \\
\text { that have flora } \\
\text { motifs, and fauna } \\
\text { motifs, namely } \\
\text { tree motifs and } \\
\text { motifs of birds } \\
\text { that are flying } \\
\text { around the tree }\end{array}$ & $\begin{array}{l}\text { The style of } \\
\text { making } \\
\text { ornaments is a } \\
\text { combination of } \\
\text { realist or } \\
\text { naturalist style } \\
\text { and stylization, } \\
\text { where trees and } \\
\text { stars are made in } \\
\text { the actual shape, } \\
\text { although in the }\end{array}$ & $\begin{array}{l}\text { The style of } \\
\text { ornament that is } \\
\text { on the facade is a } \\
\text { contemporary } \\
\text { style where the } \\
\text { ornaments are } \\
\text { formed purely } \\
\text { from the work of } \\
\text { an artist, } \\
\text { architect.. }\end{array}$ & $\begin{array}{l}\text { The ornament has a } \\
\text { function as a symbolic } \\
\text { ornament that refers to } \\
\text { the sign of a building } \\
\text { or the typology of a } \\
\text { religious building. The } \\
\text { philosophy contained } \\
\text { in the ornament is that } \\
\text { the tree of life is a door } \\
\text { of grace for humanity } \\
\text { literally to enter the }\end{array}$ \\
\hline
\end{tabular}


Identification of Architectural Ornaments of Santo Albertus Jetis Church Yogyakarta Sidhi Pramudito, Gerarda Orbita Ida Cahyandari, Muhammad Ikhsan Arifin

\begin{tabular}{|c|c|c|c|c|}
\hline $\begin{array}{l}\text { Ornament } \\
\text { Placement }\end{array}$ & Ornament Motif & Ornament Style & $\begin{array}{c}\text { Ornament } \\
\text { Pattern }\end{array}$ & $\begin{array}{l}\text { Ornament's Function } \\
\text { and Philosophy }\end{array}$ \\
\hline Church & & $\begin{array}{l}\text { form of trees that } \\
\text { do not resemble } \\
\text { tree shapes but } \\
\text { are shaped like } \\
\text { wayang gunungan }\end{array}$ & & $\begin{array}{l}\text { protection and love of } \\
\text { God through the } \\
\text { church, because the } \\
\text { path of truth and } \\
\text { eternal life is only } \\
\text { through the Lord Jesus } \\
\text { Christ. }\end{array}$ \\
\hline
\end{tabular}

Table 4. Analysis of Romo Mangunwijaya's Original Ornaments at the Santo Albertus Agung Church Jetis based on the theory of Tectonics in Architecture

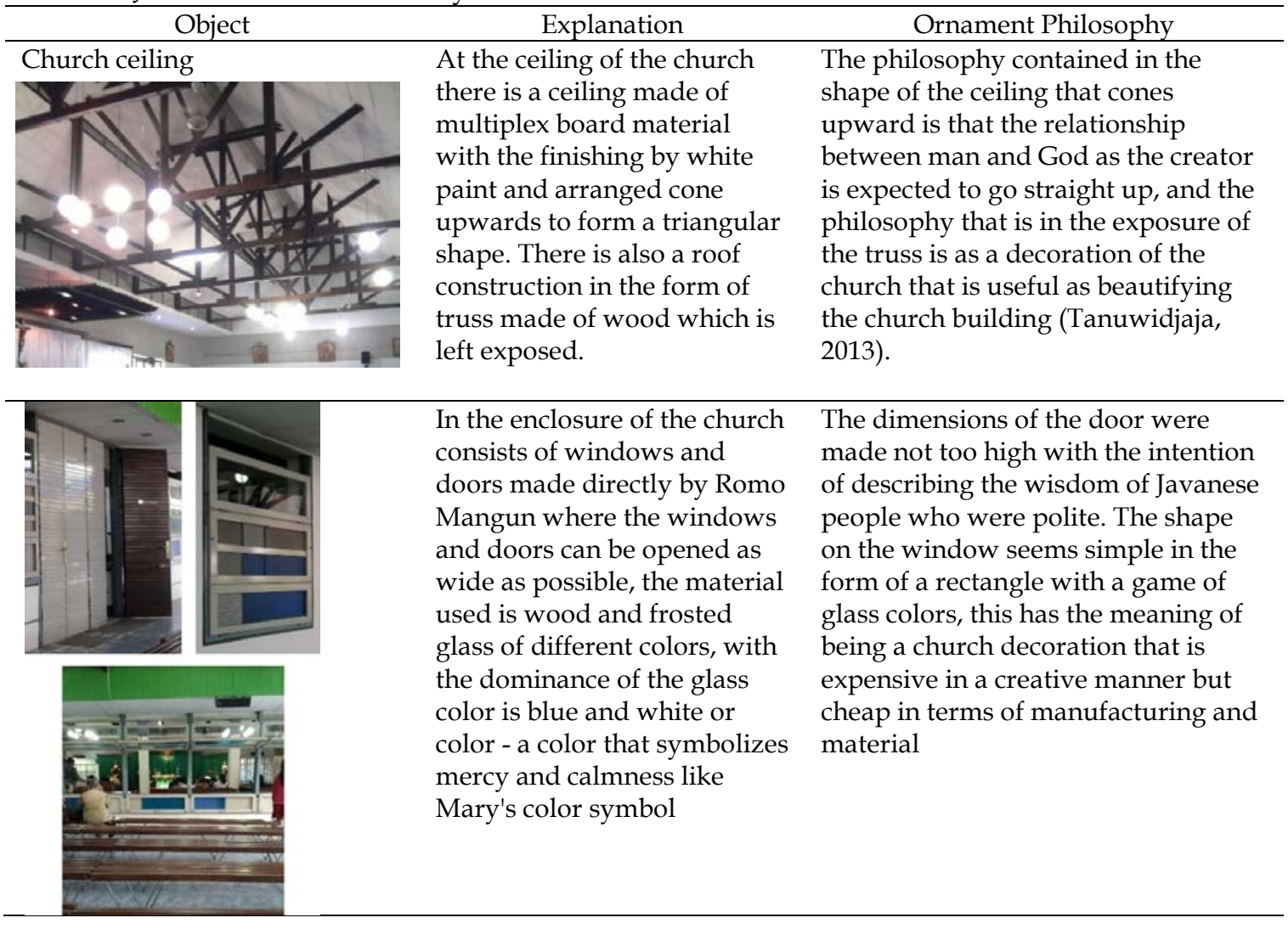

From these two analyses, some conclusions can be drawn: that ornament in Santo Albertus Agung Church Jetis is of flora and fauna motives; the styles used by Romo Mangunwijaya were of stylization and naturalism; the design was contemporary. The ornament position also holds a certain function and philosophy, e.g. the tree of life ornament on the center part of the facade functions as a point of interest as well as a symbol or sign of the building's tipology. The ornament symbolizes the door to God's grace.

Architectural tectonic principles were applied in crafting the tree of life ornament where the material used was castable refractory cement shaped as in that of Romo Mangunwijaya's creativity. It was then combined with broken softdrink glass bottles arranged in a way so as to make it a beautiful composition. 


\section{LOCAL WISDOM, Vol. 11 No. 2 July 2019}

Local Wisdom Scientific Online Journal

\section{Conclusions}

The ornament created by Romo Mangunwijaya is distinctive and unique as can be recognized from its four characteristics: local culture context, creation of ornament and its philosophical values, and architectural tectonic principles that feature true and truthful as well as exposed material construction. All of them are found in each of Romo Manungwijaya's works of architecture, e.g. Maria Asumpta Church Klaten and Sendangsono Pilgrimage Complex Kulonprogo, whose ornament shares similarities.

Santo Albertus Agung Church Jetis' ornament resembles similar features as of those of Romo Mangunwijaya's Works as have been alanyzed in his other two works and explained as follow:

- The facade ornament is of a tree of life on the west of the Church that is placed in the center as a symbol of the building's typology because it is cross-shaped and of a 'Wayang Gunungan' (wayang: Javanese traditional shadow puppet theatre; gunungan: a character in the 'wayang' shaped as a volcano) which represents Javanese culture. Its constructing materials are easy to find as it uses castable refractory cement and broken softdrink glass bottles.

- The ceiling ornament in the main building is of exposed easles made from teak wood that philosophically represents decorations beautifying a room, and of upward pointing triangular plafond symbolizing God-humans vertical relationship.

- The enclosure ornament is of wooden door and window openings beautifully combined with stained-glass composition. The width makes it possible for the air to circulate and when they are opened, it seems that there is no more border between indoor and outdoor because people can see both parts clearly.

From the analysis, it is found out that ornament is an integral part of a building design. Ornament application shoud take the building typology into considerations. To Santo Albertus Agung Church Jetis, Romo Mangunwijaya applied ornament whose shapes and interpretations help create sacred, serene and religious atmosphere for the people to worship. The result of this study is expected to be an input for the upcoming renovation so as to preserve the original ornament and to combine them with the new design so that the identity and spirit (built by Romo Mangunwijaya) remain exist for years and years afterwards.

\section{References}

Brent C.Brolin, J. R. (1982). Sourcebook of Architectural Ornament. New York: Van Nostran Reinhold Company inc.

Busono, R. T. (n.d.). Eskursi Preservasi, Konservasi, Renovasi pada Pemeliharaan Bangunan di Singapura dan Malaysia. Retrieved Maret 25, 2019, from https:/ / www.academia.edu/6958359/: https://www.academia.edu/6958359/ESKURSI_PRESERVASI_KONSERVASI_REN OVASI_PADA_PEMELIHARAAN_BANGUNAN_DI_SINGAPURA_DAN_MALAYS IA

I Wayan Sudana, I. W. (2005). Bahan Ajar MK. Ornamen. Gorontalo: Jurusan Teknik Kriya, Fakultas Teknik, Universitas Negeri Gorontalo. 
Identification of Architectural Ornaments of Santo Albertus Jetis Church Yogyakarta Sidhi Pramudito, Gerarda Orbita Ida Cahyandari, Muhammad Ikhsan Arifin

Leevianto, J. D. (Volume 01, Nomor 02, edisi April 2017). The Architectural Tectonics of Y.B. Mangunwijaya's Design at The Holy Virgin Mary's Cage Complex in Sendangsono. Jurnal RISA (Riset Arsitektur), 83-99.

Mangunwijaya, Y. (1988). Wastu Citra: Pengantar keilmu Budaya Bentuk Arsitektur Sendi-Sendi Filsafatnya Beserta contoh-contoh Praktis. Jakarta: PT. Gramedia.

Mulyatno, C. (November 2013). Keutamaan dalam Karya-karya Kemanusiaan YB. Mangunwijaya. Jurnal Teologi Vol. 02 No. 02, 185-198.

Setyoningrum, Y. (2012). Analisa Citra Estetik Arsitektur sebagai Media Inkulturasi Budaya pada Gereja Katolik. Bandung: Jurusan Desain Interior, Fakultas Seni Rupa dan Desain, Universitas Kristen Maranatha.

Siwu, M. J. (2016). Pendekatan Sakralisme Pada Banguna Gereja Masehi Injil Minahasa. DASENG, 92-103.

Tanuwidjaja, L. (2013). Gaya Desain Pada Interior Gereja Katolik Santo Albertus Magnus Jetis Yogyakarta. Jurnal Intra Vol. 1 No. 2, 1-7. 